\title{
CRAFTSMANSHIP AND ARTISTIC ANALYSIS IN INTERPRETATIONS
}

\author{
Abduhamid Kholmurodov
}

Doctor Of Philological Sciences, Professor, Navoi State Pedagogical Institute

\section{ABSTRACT}

The article discusses in detail the contribution of literary critic D. Turaev to the current development of Uzbek literary criticism, the analysis of news and changes in the literary process, the features of new interpretations. Criticism of Munaqqid's analysis of works of art, his skill in the study of poetic and prose works created and being created during the years of independence.

KEYWORDS:- literary, creative, artistic, article, scientific, art, aesthetics, process, modernism, interpretation.

\section{INTRODUCTION}

Literary criticism plays an important role in the timely and objective assessment of changes in the literary process, innovations, and artistic discoveries. Understanding a literary work, understanding the essence of artistic aesthetic principles, literary criticism in revealing its peculiarities, is, so to speak, one of the veins of the literary process. "Literary criticism" says the theoretical source, "in particular, the main source of ideas about interpretation is the study of receptive aesthetics". There is a civilized person who follows the path of respecting, learning and mastering values. It is a complex process, a state of mind. Assimilation of values is the subject of receptive aesthetics. While the art of assimilation describes the process of assimilation of values, in particular, the adoption of works of art, the literary interpretation is a state of assimilation, the return of beauty to life, the state of rebirth as an enriched value" [1, p. 303], says the textbook "Uzbek Literary Criticism".

\section{THE MAIN FINDINGS AND RESULTS}

Well-known critic Damin Turaev's book "Interpretations of the spiritual world" contains a scientific analysis of new approaches to Uzbek prose and poetry of the independence period, research, features of creative experience in world literature, and the importance of traditional poetic forms in the development of rhetoric and other current issues of literature. Literary scholar Umarali Normatov, in his preface to the book, spoke about the author's contribution to the development of Uzbek literary criticism. Including:

"The scientist constantly monitors the literary process and its innovations, tries to talk about the best works that can enrich our national 
CURRENT RESEARCH JOURNAL OF PHILOLOGICAL SCIENCES 2(5): 28-32,

May 2021 DOI: https://doi.org/10.37547/philological-crjps-02-05-09

ISSN 2767-3758

(C)2021 Master Journals

\section{Crossref do) 81 Google}

Accepted25 th May, 2021 \& Published 31 ${ }^{\text {th }}$ May, 2021

literature, to acquaint readers with their content" $[2$, p. 8], he says.

Famous Kyrgyz literature Chingiz Aitmatov's works are well known to Uzbek readers. Almost all of the author's works have been translated into Uzbek. The resolution of the President of the Republic of Uzbekistan "On the wide celebration of the 90th anniversary of the great writer and public figure Chingiz Aitmatov" adopted in April 2018 shows that the work of the worldrenowned artist is highly valued by Uzbek readers. The author's latest novel "Cassandra's seal" is distinguished by the complexity of the plot, the peculiarity of the compositional structure. Understanding, comprehending, feeling the main idea of the work, the system of images and their artistic interpretation, the writer's unique skill in the artistic representation of real reality requires much deeper thinking, ingenuity. Undoubtedly, reading the article of the critic D.Turaev "Artistic imagination and myths of the time" devoted to the analysis of this work will be of great help to the reader.

The novel "Cassandra's seal" was translated by Suyun Karaev in 2007 and published under the title "Signs of the End Times". In the novel, the world is on the verge of destruction, and terrible tragedies await humanity. Such works have been created before in world literature. Honore de Balzac's Catherine the Medici and Prosper Merimee's Chronicle of the reign of Charles IX accurately portray the consequences of the Civil War at that time. By the time of Chingiz Aitmatov, the world's conflicts and global catastrophes have changed and become even more terrible. The critic explains what these tragedies and catastrophes are based on from the artistic interpretation of the events based on the plot of the work:

"Chingiz Aitmatov also provides valuable information about the evils and disasters on the planet through the letter of the space priest
Philopheus about the terrible crimes committed by man. These include the planting of landmines under the guise of powerful states such as the United States and the Soviet Union in order to exterminate the local population in the decadelong war in Afghanistan, the images of the relatives of the deceased exploding by touching the corpse and watching the invading soldiers rejoice that they too will be shaken shake the heart of the reader. When did the qualities of these soldiers, who enjoy evil and murder, appear in their genes and nature?" [3, p. 18].

Kyrgyz scholar R. Rakhmonaliev says in his article "Philosophical Discoveries of Chingiz Aitmatov" that the author discovered a novel that synthesized art, philosophy and fiction. Munaqqid D.Turaev agreed with this opinion of the scientist and was able to prove scientifically how these aspects were mixed in the novel "Cassandra's seal".

Poet, writer, statesman and politician Sharof Rashidov is one of the figures who will live forever in the hearts of the Uzbek people. His political and creative activity has been severely tested in difficult periods of the history of our people. The death of the man who led our people under colonial oppression for almost a quarter of a century, who protected it from all kinds of misfortunes, injustices and humiliations, was unjustifiably condemned. At the behest of Moscow and the black forces sent from there, an attempt was made to destroy the historical services of the great man, to discredit him. False accusations of "cotton affair" and "Uzbek affair" were fabricated and thousands of people were repressed. Fortunately for our people, the winds of independence soon began and our country has embarked on a new path of development. During this period, one of the first noble deeds of the leaders of the republic was to justify the personality of Sh. Rashidov, to recognize his work as a great statesman and politician, to study and appreciate his rich creative heritage as 
CURRENT RESEARCH JOURNAL OF PHILOLOGICAL SCIENCES 2(5): 28-32,

May 2021 DOI: https://doi.org/10.37547/philological-crjps-02-05-09

ISSN 2767-3758

(C)2021 Master Journals

\section{Crossref do) 81 Google}

Accepted25 $5^{\text {th }}$ May, 2021 \& Published 31 ${ }^{\text {th }}$ May, 2021

a poet and writer. The 80th and 100th anniversaries of the poet, writer, statesman and politician have become major celebrations across the country. In his article "Song of Peace, Creativity and Friendship of Peoples", the critic expressed his sincerity:

"It should be noted that during the very difficult and difficult years of Sharof Rashidov's presidency in the former Soviet Union, Uzbekistan's global recognition and the development of our culture, especially its fame in the international arena, contributed greatly. For example, Uzbekistan has become a center of peace and friendship, supplying agricultural machinery to Asia, Africa, Latin America, Cuba and many other countries, hosting international conferences in the field of literature and art" [3, p. 35].

Rashidov was a well-known poet before reaching the level of head of state. Many of his poems are dedicated to the creativity of labor, in which important events in the history of our people are poetically reflected. Songs based on many of the poet's poems were created and became very popular among our people. Later, the poet also tested his talent in prose and created a number of artistically energetic prose works. Among them are the novels "Mighty Wave", "Winners", "Kashmir Song", "Epic of Two Languages". Munaqqid D.Turaev thought about the author's novel "Winners" in detail. It has been scientifically proven that the real reality that gave rise to the idea of the work was the fact that the work was first born in the genre of short stories, and then reworked the system of images, made significant changes in the composition and plot of the work. The article is important in understanding the current significance of the work of the writer and poet Sh. Rashidov, the relevance of the universal ideas glorified in it.

The terms modernism, postmodernism, surrealism, existentialism, neomodernism, and absurd literature have long appeared in world literature. A new artistic interpretation of reality, initiated by such writers as J. Joyce, M. Proust, A. Camus, F. Kafka, is to some extent reflected in the literature of all nations today. In fact, these innovations go back a long way, to the era of ancient literature, without growing out of space. There is a great deal of research by European literary critics that J. Joyce's The Adventures of Ulysses is in tune with Homer's Odyssey. Writers and poets working in Uzbek literature under the influence of modern literature have presented a number of works to readers during the years of independence. Among them, the creative experience of the writer Khurshid Dostmuhammad is noteworthy. In his stories, narratives and novels, we encounter a new approach, a new interpretation, a new image in the artistic representation of reality. The novel The Wise Sisyphus is one such work. The critic commented on the work in the article "The legend of Sisyphus in the interpretation of Uzbek literature". Prior to creating the novel, the writer had shown himself to be a writer with a distinctive style in a number of stories and narratives. His story, The Sun of Knova, chronicles the lives of farmers and hunters in the Americas as they explore new lands. Or the story "Above the Rocks" depicts the contradictions between man and nature, between nature and the animal world. At the same time, the writer was inspired by the experiences of such representatives of world literature as Chingiz Aitmatov, Jack London, A. Paustovsky, M. Prishvin. Dostoevsky's love story "My Love is You", the story of the American writer, the singer of mysterious worlds Edgar Allan Poe "Al-A'raf" revealed new aspects of the writer's creative research. The critic emphasizes that the novel "The Wise Sisyphus" is valuable because the author interpreted the ancient Greek mythology in the Uzbek spirit, and this was the first experience. 
CURRENT RESEARCH JOURNAL OF PHILOLOGICAL SCIENCES 2(5): 28-32,

May 2021 DOI: https://doi.org/10.37547/philological-crjps-02-05-09

ISSN 2767-3758

(C)2021 Master Journals

\section{Crossref do) 81 Google}

Accepted25 th May, 2021 \& Published 31 ${ }^{\text {th }}$ May, 2021

The article "Friends", "Hat", "Punishment of the Nationalist", "Monologue" by the author Khayriddin Sultan in the article "Interpretations of time and human destiny in Today's Stories" are scientifically analyzed. These stories were published in the 1st issue of "Sharq Yulduzi" magazine in 2019. It is obvious that the literary critic D.Turaev regularly observes the literary process and expresses his reaction to each literary event. In the analysis of stories, too, not only narrates their plot from beginning to end, but also distinguishes aspects in which the writer's unique style is reflected, analyzes the role of artistic details in revealing the ideological and aesthetic essence of the work. In order to substantiate his scientific observations, he refers to the experiences of world literature, trying to show the influence of artistic experiences, creative experiences in the best stories created in Uzbek literature. The stories depict the social injustices of the recent Soviet era, the discrimination of the individual, the unresolved problems of everyday life, the suffering of people in a unique artistic style and means.

The work of Sirojiddin Sayyid, described by Umarali Normatov as one of the leading artists of our time, has not yet been sufficiently studied. Accordingly, the study "Gardens of the spiritual world in poetry" is one of the most extensive and in-depth scientific analysis of the work of the talented poet. It includes aspects of Sirojiddin Sayyid's talent as a poet, collections of poems, poems from "Selection" and "Selected Works", the charm of the poet's pen in his epics; the originality of poetic images, the continuation and enrichment of creative experience and traditions in difficult metaphors, the diversity of themes and the features of methodological originality are analyzed. Sirojiddin Sayyid is a poet who enjoys the works of Alisher Navoi and Zahiriddin Muhammad Babur, learns and draws inspiration from the spiritual garden they created, and successfully continues the traditions of our classical poetry.

"Sirojiddin Sayyid says the critic, does not write words that are arrogant, false, silent, or arrogant. He describes not himself, but our Motherland, ordinary rural landscapes, places of joy that grew up in his childhood, the image of the time. A number of poems written during the years of the poet's artistic research on the path of creative maturity clearly prove this idea" [3, p. 96].

The poet's poems "Bu alam", "Peshona haqida", "Hikmat", "Umr asta aylanarkan", "Dunyo nadir", "Dunyoning tubi", "Kichik qalbim" contain significant poetic ideas and philosophical generalizations are emphasized to be vital. In his poems, which reflect his childhood memories, the poet enlivens the rural landscapes, the immaculate world of childhood in the eyes of the reader like an artist.

In the pre-independence period, the poet's works condemned social injustice, and the Uzbek peasant's pity for his hard life was expressed in moving verses. The poem "Unlucky Farmer" is one of such works. In it, one is deeply saddened by the tragic fate of the Farmer, his failure, his lack of enlightenment in life. The farmer, who has worked all his life, leaves this world, nothing is left of him, the house he lived in is quickly destroyed, and his donkey is eaten by wolves. Simple words, the expression of a deep tragedy in a seemingly simple, fluffy image, have the power to keep the poet awake. This is the skill of the poet. Such authenticity is the main feature of most of Sirojiddin Sayyid's poems. This is emphasized by the critic, who gives vivid examples of this.

\section{Conclusion}

The article also discusses the works of the poet in the ghazal genre, one of the main poetic genres of our classical literature, the artistic features of the muhammads associated with the ghazals of Alisher Navoi, the scientific analysis of the poet's 
CURRENT RESEARCH JOURNAL OF PHILOLOGICAL SCIENCES 2(5): 28-32,

May 2021 DOI: https://doi.org/10.37547/philological-crjps-02-05-09

ISSN 2767-3758

(C)2021 Master Journals

Crossref dof 81 Google

Accepted25 $5^{\text {th }}$ May, 2021 \& Published 31 ${ }^{\text {th }}$ May, 2021

talents and peculiarities. In general, the poet applauds Alisher Navoi's deep respect for his genius throughout his career. The poet repeats this over and over again in his poems:

The poet says.

...To Navoiy bor-muhabbat dildadir,

So'lmagay hargiz ko'ngil bo'stonimiz [3, p. 150].

... For Navoi there is love in the heart,

We will never be disappointed.

Isajon Sultan's novel "The Eternal Wanderer" in his article "Artificial Man and the Eternal Wanderer" calls it a purely philosophicaladventure novel. "If Western postmodernism rules the world as nonsense, Isajon Sultan's novel will promote the idea of avoiding wandering in a seemingly meaningless world" [4, p. 179], he said.

The book includes "Interpretation of the people's psyche", "Who is on the side of the author?", "Artificial man and the eternal wanderer", "Sacrifice of literary science", "Interpretation of destinies", The important features of the current literary process, the rise of artistic thinking, the scientific activity of literary scholar, academician B. Nazarov, the success of the creative research of Abdukayum Yuldashev, Isajon Sultan, Nazar Eshankul, with contemplation on the important and topical tasks facing literary criticism today. The book of the hard-working scholar D.Turaev, consisting of these scientific and literary articles, is important in understanding the current literary process and in correctly understanding, analyzing and drawing conclusions from the factors of today's rise of Uzbek literature.

\section{REFERENCES}

1. Nazarov B. et al. (2012) History of Uzbek Literary Criticism. - Tashkent: "Tafakkur Kanoti". - p. 303. (Назаров Б. ва бошқалар, Ўзбек адабий танқиди тарихи, Тошкент,
“Tafakkur qanoti”, 2012й. Б. 303.)

2. Normatov Umarali. (2020) Literary scholar and kind contemporary. In place of the foreword, Damin Turaev, "Interpretations of the spiritual world". - Tashkent: Akademnashr. - p. 8. (Норматов Умарали, Адабиётшунос олим ва дилкаш замондош, Сўзбоши ўрнида, Дамин Тўраев, “Маънавий олам талқинлари", Тошкент, “Akademnashr", 2020 й. Б.8.)

3. Turaev Damin. (2020) Interpretations of the spiritual world. Literary and scientific articles. - Tashkent: Akademnashr. - pp. 15/35/96. (Тўраев Дамин, Маънавий олам талқинлари, Адабий-илмий мақолалар, Тошкент, “Akademnashr", 2020 й. Б.15/35/96.)

4. Independence. Literature. Criticism. Interviews based on questions from writer and literary critic Ulugbek Hamdam. Quronov Sadullo answers. - Tashkent: "Turon zamin ziyo". 2015. - p. 179. (Истиқлол. Адабиёт. Танқид. Ёзувчи ва адабиётшунос Улуғбек Хамдам саволлари асосида қурилган сухбатлар. Қуронов Саъдулло жавоблари, Тошкент, “Turon zamin ziyo", 2015 й. Б.179.) 